\title{
ECOTOXICOLOGY OF GREEN SYNTHESIZED SILVER NANOPARTICLES ON FRESH WATER FISH
} MYSTUS GULIO

\author{
ABIRAMI T. ${ }^{1}$, ALEN GODFREY R. JOSE ${ }^{1}$, BAVANI GOVINDARAJULU ${ }^{2}$, KARTHIKEYAN J. ${ }^{* 1}$ \\ ${ }^{1}$ Department of Zoology, Presidency College (Autonomous), Chennai, India, ${ }^{2}$ Deartment of Zoology, Queen Mary's College (Autonomous), \\ Chennai, India \\ Email: j_karthikeyan@hotmail.com
}

Received: 26 Jul 2017 Revised and Accepted: 21 Sep 2017

\begin{abstract}
Objective: Nanotechnology an advanced tool to synthesis atomic level particles. Increased application of silver nanoparticles results in the bioaccumulation of these particles in the environment. The biological effect of the green synthesized silver nanoparticles on the fresh water cat fish ws studied in the present study.

Methods: Asystasia gangetica leaf extract was used to synthesize silver nanoparticles, the particles were characterized by scanning electron microscopy. Fifteen days after the introduction of fishes into the medium containing AgNPs, the fishes were sacrificed and the tissues were processed for biochemical and histological studies. $\mathrm{Na}^{+}-\mathrm{K}^{+}-\mathrm{ATPase}$ was estimated using LeBel method. Estimation of carbohydrate was done by the Phenol-sulphuric acid method. Total protein was estimated using Lowry's method, Sulpho-Vanilline method was used to estimate the total lipids.

Results: The results observed in the present study reveals a marked difference in the level of carbohydrate in the muscle tissue from $48.338 \pm 0.320$ to $22.747 \pm 1.837 \mu \mathrm{g} / 100 \mathrm{mg}$ wet tissue followed by gills and liver with $41.21 \%$ and $25.48 \%$ decrease. Total protein content was decreased from $649.094 \pm 1.429$ to $491.56 \pm 0.925 \mu \mathrm{g} / \mathrm{mg}$ wet tissues. The drastic increase in the total lipids was observed in liver tissue of treated fishes from $0.240 \pm 0.004$ to $0.408 \pm 0.005 \mathrm{mg} / \mathrm{gm}$ wet tissue. $\mathrm{Na}^{+}-\mathrm{K}^{+}$-ATPase activity of liver tissue increased from $0.153 \pm 0.001$ to $0.225 \pm 0.003$ in the liver tissue of treated fishes, followed by muscles and gills with $33.61 \%$ and $35 \%$ of the increase in the activity. Marked changes in the structure of gills with degenerated primary gill lamellae, necrosis, hyperplasia and fused primary lamellae were evident in experimental group. Necrosis, vacuolization, disintegrated nucleus and blood sinusoids were observed in liver tissues. Disintegration of myofibrils was evident in AgNP treated group of fishes.
\end{abstract}

Conclusion: The plant-mediated synthesized AgNPs shows a potential toxic effect on all the tissues studied; changes were observed in the normal architecture of tissues as well as in the biochemical parameters. To understand the mechanism of toxicity of these particles further studies at the molecular level has to be carried out.

Keywords: Asystasia gangetica, Silver nanoparticles, Mystus gulio, $\mathrm{Na}^{+}-\mathrm{K}^{+}-\mathrm{ATPase}$

(C) 2017 The Authors. Published by Innovare Academic Sciences Pvt Ltd. This is an open access article under the CC BY license (http://creativecommons.org/licenses/by/4.0/) DOI: http://dx.doi.org/10.22159/ijpps.2017v9i11.21627

\section{INTRODUCTION}

Nanotechnology paved way for the synthesis of atomic level particles and increased the knowledge of intracellular structure at the molecular level. Nanosized nature of these particles enables the delivery and biocompatibility of drugs [1]. The high-level mobility of the nanoparticles in the environment and living organisms are due to their very small size [2]. Nanoparticle toxicity is increased due to the adherence of particles to the cell membrane [3]. The increased applications of nanosized metallic material leads to the accumulation of their particles in the environment [4]. The properties of the nanomaterials raise concern on the adverse effect of toxicity on biological systems. The nature of nanoparticles and its interaction with biotic and abiotic factors were apparent and this may lead to the risk of human and environmental health [5]

Silver nanoparticles are widely used in the field of medicine due to its quantum size and surface area to volume ratio. About $56 \%$ of the global nanoparticle is dedicated to silver nanoparticles [6]. Silver nanoparticles are being used in the field of electronics [7], and targeted drug delivery system [8]. In the diagnosis treatment of gloma and stroke [9], Stain resistant clothing [10], larvicidal and bactericidal [11] on cancer therapeutics [12] and cosmeceuticals [13]. As a result of its distinctive physico chemical properties wide applications of silver nanoparticles and its effect on the biological systems is of great concern. Silver nanoparticles cause cytotoxicity, oxidative stress and inflammatory responses in fish and aquatic organisms [14]

The aquatic medium is at high risk for the exposure of nanoparticles and other toxicants as the medium acts as a sink for the particles discharged from the industries and various sources. The effect of silver nanoparticles on the Japanese medaka [15], Zebrafish [16] and Rainbow trouts [17] proves the toxic effect of silver nanoparticles on these organisms. AgNPs causes damage to the nuclear material of the blood erythrocyte [18]. The fate and behaviour of nanomaterials are different in freshwater and marine environments as it depends on the hydrophilic and hydrophobic nature of the particles [19]. Increased enzyme activity due to lead nanoparticles exposure in chloride cells may induce Osmo-ionic regulation of the gills [20]. The applications of nanoparticles are increasing in the day to day life, however, the impact on the environment and health remains unresolved. The paucity of information available on the toxicological effects of green synthesized silver nanoparticles in the aquatic as well as its effects on ecosystem [21]. It is required to understand the interaction of nanoparticles with the living system in cellular and genetic level for the long-term clinical and commercial applications of the green synthesized silver nanoparticles.

Mystus gulio [22] is an omnivorous bagrid fish, which is distributed all along the shores of many Asian countries, especially in estuarine and tidal waters [23]. Due to euryhaline and hardy nature of this species, it can be cultured in fresh, brackish and seawater [24]. It is very delicious and it is of high consumer preference and market demand in many Asian countries including India [25]. As the application of nanoparticles in one way or other become more evident, it is necessary to analyze the nature of the plant-mediated synthesized silver nanoparticles on freshwater fishes. Hence, in the present study, a preliminary attempt has been made to study the role of plant-mediated synthesized silver nanoparticles impact on the fingerlings of Mystus gulio. 


\section{MATERIALS AND METHODS}

\section{Chemicals and reagents}

Silver nitrate, sulphuric acid, trichloroacetic acid, Phenol, bovine serum albumin (BSA) vanillin, amino napthol sulfonic acid (ANSA), and adenosine triphosphate were obtained from HiMedia (HiMedia Laboratories Pvt Ltd. Mumbai). All the other chemicals of analytical grade were procured from Merck Limited (Mumbai, India).

\section{Synthesis of silver nanoparticles}

Silver nanoparticles were synthesized using Asystasia gangetica leaves as reducing agents. Freshly prepared leaf extract was mixed with a different concentration of silver nitrate solution. The reaction mixture was stirred continuously at room temperature and the color change was noted and lambda max was observed using UVSpectroscopy.

\section{Characterization of silver nanoparticles}

The UV-Visible spectroscopy was used to characterize the silver nanoparticles. The reducing of Ag-NPs in the reaction mixture was continuously monitored by measuring the lambda max of the reaction mixture. The reaction of silver was continuously monitored by measuring the surface resonance of SNPs in the wavelength ranges from $300 \mathrm{~nm}$ to $1100 \mathrm{~nm}$. The size and shape of the green synthesized nanoparticles were analyzed using scanning electron microscopy.

\section{Experimental design}

Mystus gulio fishes were collected from local fish ponds and were acclimatized in laboratory condition for $15 \mathrm{~d}$ and the fishes were fed ad libitum. Acute toxicity of silver nanoparticles was carried out in Mystus gulio and the lethal concentration was calculated with 2, 4, 6, $810 \mathrm{ppm}$ and the mortality was observed for a period of $96 \mathrm{~h}$ to calculate the $\mathrm{LC}_{50}$ value. The acute toxicity test was carried out with sublethal dose of $0.4 \mathrm{mg} / \mathrm{l}$. The silver nanoparticles were dissolved in the aqua medium before dilution and the solution mixture was sonicated for $20 \mathrm{~min}$. The fishes were fed ad libitum during experimental period and they were maintained for a period of $15 \mathrm{~d}$. After $15 \mathrm{~d}$ the fishes were sacrificed. Tissues namely muscles, gills and liver were dissected out and rinsed with ice-cold saline and stored at $20{ }^{\circ} \mathrm{C}$ till further analyses. A portion of the tissues was fixed with $10 \%$ formalin for light microscopic studies.

\section{Biochemical studies}

Biochemical parameters were studied in gills, liver and muscle of the freshwater fish Mystus gulio. The total protein content was determined using Lowry's method [26] with Folin-phenol reagent. Total carbohydrates present in the Trichloro Acetic Acid (TCA) soluble tissue extracts were estimated by Oligo and polysaccharide sensitive Phenol-sulphuric acid method [27]. Total lipid content was estimated using sulfo-vanillin method [28]. $\mathrm{Na}^{+}-\mathrm{K}^{+}-\mathrm{ATPase}$ activity was estimated by $\mu \mathrm{g}$ pi liberated/minute [29].

\section{Light microscopy}

The formalin-fixed tissues were cleared using Tetrahydrofuran as dehydration and clearing agent. The cleared tissues were paraffin (Melting point, $56^{\circ} \mathrm{C}-60{ }^{\circ} \mathrm{C}-\mathrm{BDH}$ ) embedded and cut serially into 5 $\mu \mathrm{m}$ sections for histological studies. The sections were deparaffinized in xylene, hydrated through alcohol series and stained in aqueous Delafield hematoxylin for 2-5 min. The stained sections were water washed dehydrated and counterstained with $0.1 \%$ Eosin in $95 \%$ alcohol for 15-20 seconds. On further dehydration and clearing in xylene, they were mounted in DPX [30].

\section{Statistical analysis}

Data analysis and " $t$ " test were performed using [31] and a value of $\mathrm{p}<0.05$ was considered significant.

\section{RESULTS}

Formation of silver nanoparticles was confirmed by the appearance of the intense yellow-brown colour of the solution. The formation of silver nanoparticles can be correlated with respective UV-Vis spectra (fig. 1). The spectra exhibit the formation of colloidal silver with a strong absorbance of 409-424 $\mathrm{nm}$.

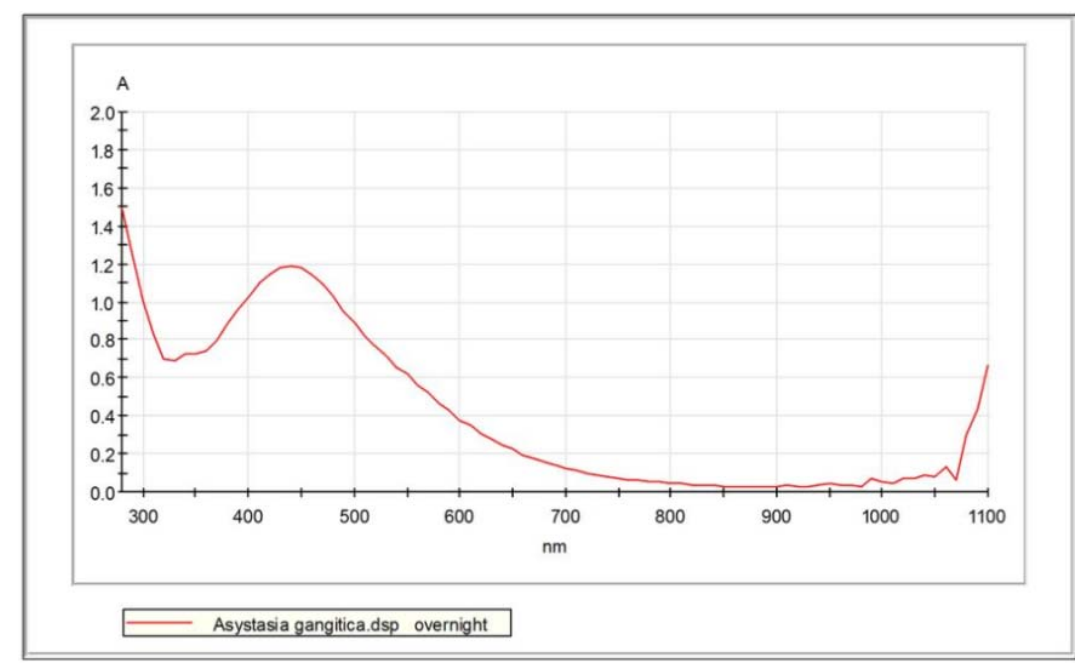

Fig. 1A: UV-VIS absorption spectra of silver nanoparticles synthesized from Asystasia gangetica leaves at 1 mmol silver nitrate

The carbohydrate content of various tissues such as liver, gills, and muscles of Mystus gulio were studied in control as well as green synthesized silver nanoparticles exposed fishes and the results were presented in table 1 . The data reveals a drastic decrease in the level of carbohydrate in all the tissues studied. A maximum of $52.94 \%$ decrease was observed in muscles followed by $41.21 \%$ and $25.48 \%$ in gills and liver respectively, the total protein content of control and silver nanoparticles treated fishes were estimated and the results were presented in table 1 . A significant reduction in the level of protein was observed in liver tissue of AgNP's treated group when compared to control animals. In gills and muscles, a marginal decrease in the level of protein was observed and the decrease amounts to $24.26 \%$, $10.17 \%$ and $5.83 \%$ in liver, muscle, and gills, respectively. Table 1 reveals that the results of the total lipid content in the liver, muscle, and gills of control and green synthesized silver nanoparticles treated freshwater fish Mystus gulio. Observation of results reveals a drastic increase in the level of total lipid content in liver and gill tissues. A maximum increase was observed in the liver tissue of treated fishes. 


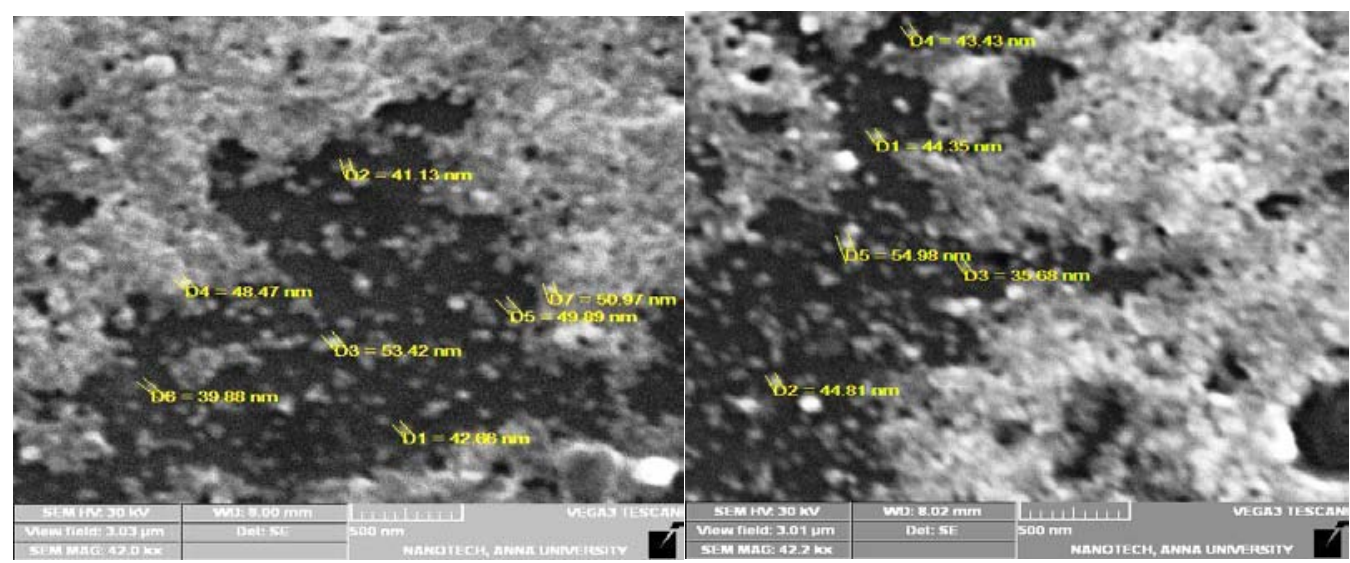

Fig. 1B: Scanning electron microscopic image of silver nanoparticles synthesized using crude leaf extracts Asystasia gangetica

Table 1: Total carbohydrate ( $\mu \mathrm{g} / 100 \mathrm{mg}$ wet tissue), protein and lipid ( $\mathrm{mg} / \mathrm{gm}$ wet tissue) present in various tissues (liver, gill and muscles) of control and plant-mediated synthesized silver nanoparticles treated freshwater fish Mystus gulio

\begin{tabular}{lllll}
\hline & Tissues & Control & AgNP Treated group & Percentage of change \\
\hline \multirow{3}{*}{ Carbohydrate } & Gill & $36.814 \pm 2.091$ & $21.647 \pm 0.585^{*}$ & 41.21 \\
& Liver & $356.47 \pm 2.072$ & $265.62 \pm 1.868^{*}$ & 25.48 \\
& Muscle & $48.338 \pm 0.320$ & $22.747 \pm 1.837^{*}$ & 52.94 \\
Protein & Gill & $229.454 \pm 0.535$ & $216.054 \pm 0.462$ & 24.26 \\
& Liver & $649.094 \pm 1.429$ & $491.564 \pm 0.925^{*}$ & 10.17 \\
& Muscle & $608.864 \pm 1.383$ & $546.914 \pm 1.365$ & 65.21 \\
Lipid & Gill & $0.219 . \pm 0.004$ & $0.362 \pm 0.010^{*}$ & 70 \\
& Liver & $0.240 \pm 0.004$ & $0.408 \pm 0.005^{*}$ & 5.28 \\
\hline
\end{tabular}

Values expressed are mean \pm SEM of six fishes in each group, *Significance at $\mathrm{p}<0.05$, Observation of results in table 2 reveals that the activity of $\mathrm{Na}^{+}-$ $\mathrm{K}^{+}$-ATPase was increased marginally in green synthesized silver nanoparticles exposed group, where the decrease amounts to $47.05 \%$, $35 \%$, $33.61 \%$ with reference to liver, gill and muscle tissues of the treated fishes.

Table 2: $\mathrm{Na}^{+}-\mathrm{K}^{+}-\mathrm{ATPase}$ activity ( $\mu \mathrm{g}$ pi liberated/mg proteins/min) of the control and silver nanoparticles treated fresh water fish Mystus gulio

\begin{tabular}{llll}
\hline Tissues & Control & AgNP treated group & Percentage of change \\
\hline Gill & $0.120 \pm 0.002$ & $0.167 \pm 0.0002^{*}$ & 35 \\
Liver & $0.153 \pm 0.001$ & $0.225 \pm 0.003^{*}$ & 47.05 \\
Muscles & $0.119 \pm 0.003$ & $0.159 \pm 0.001^{*}$ & 33.61 \\
\hline
\end{tabular}

Values expressed are mean \pm SEM of six fishes in each group, *Significance at $\mathrm{p}<0.05$

Light microscopic observations in the tissues of Mystus gulio fishes treated with SNP are presented in fig. 2-4. Primary and secondary lamellae of gills with pillar cells and also the presence of chloride cells were evident in control animals. Fishes exposed to green synthesized silver nanoparticles shows necrosis in the gill arch (GA) and fusion of primary and secondary lamellae. Observation reveals hyperplasia and aneurism. The liver was covered with serous membrane and some connective tissues were extended in the parenchyma. In the control tissue presence of polygonal hepatic cells with a clear spherical nucleus was evident. The presence of glycogen granules was also observed and necrosis of hepatocytes was evident in the treated groups. The shape of the cells with irregular vacuolization was also observed in AgNP's treated liver tissue of freshwater fish Mystus gulio. The muscle tissue of control fishes shows the bundle of myofibrils with welldefined striation.

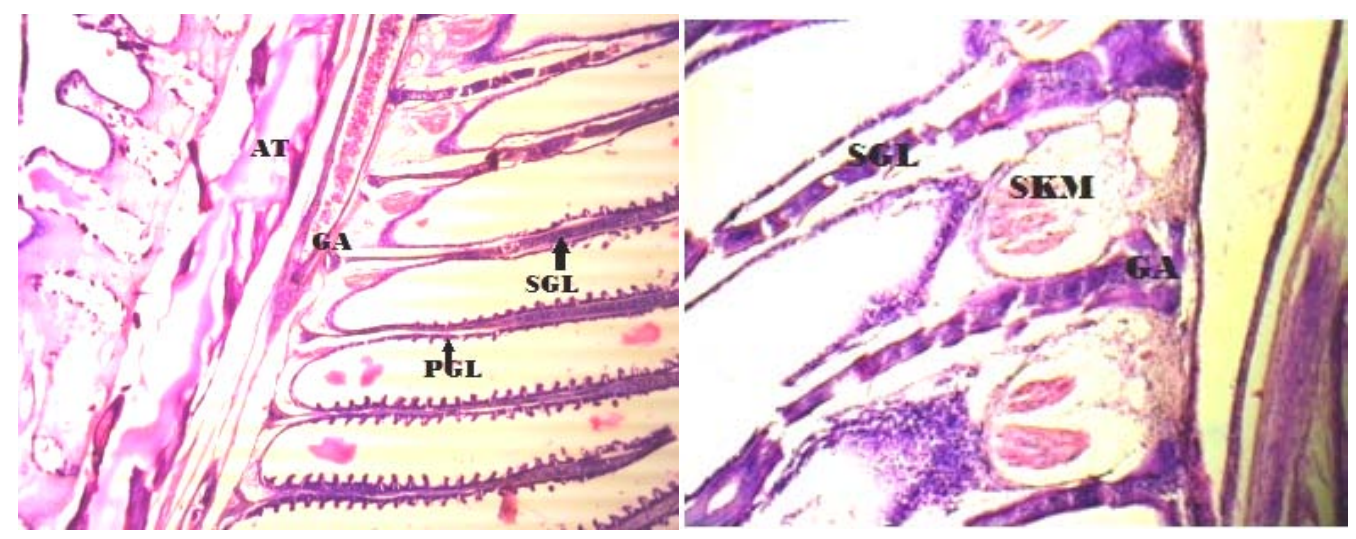

Fig. 2A: Morphology of gills of control fresh water catfish Mystus gulio. SGL-secondary gill lamellae, GA-Gill arch, AT-Adipose tissue, PGLprimary gill lamellae, SKM-skeletal muscle fibre 


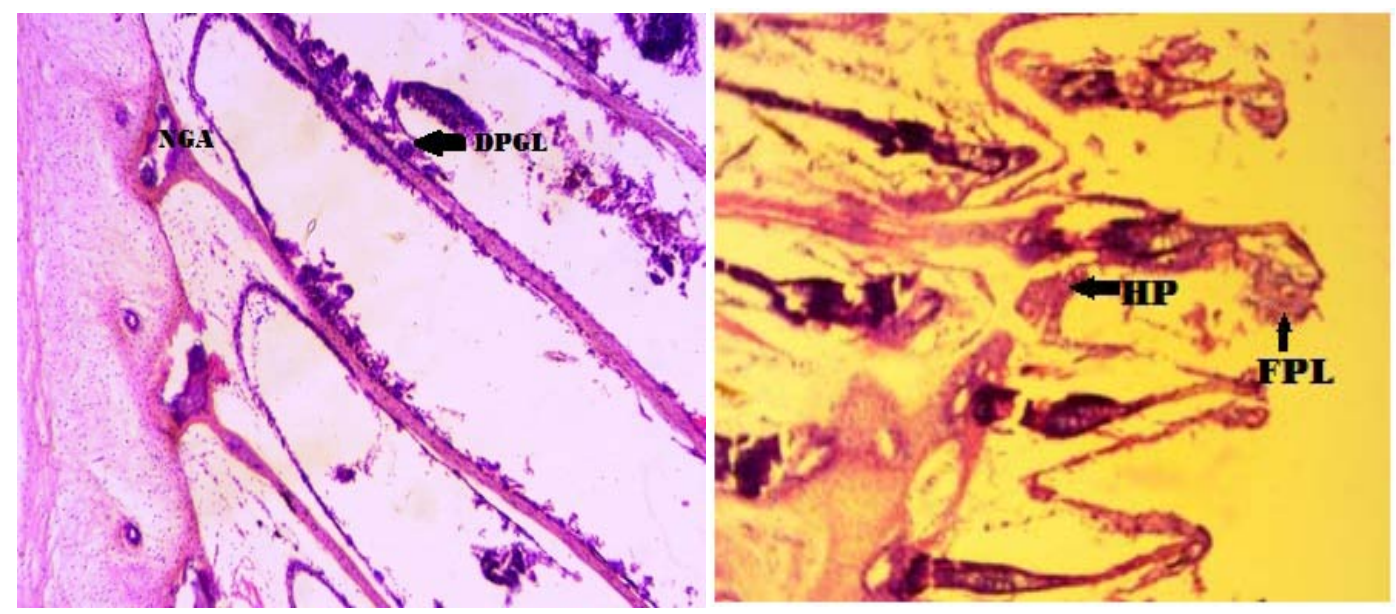

Fig. 2B: Gill morphology of green synthesized silver nanoparticles treated fresh water cat fish Mystus gulio. DPGL-Degenerated primary gill lamellae, N-Necrosis, Hp-Hyperplasia, FPL-Fused primary lamella

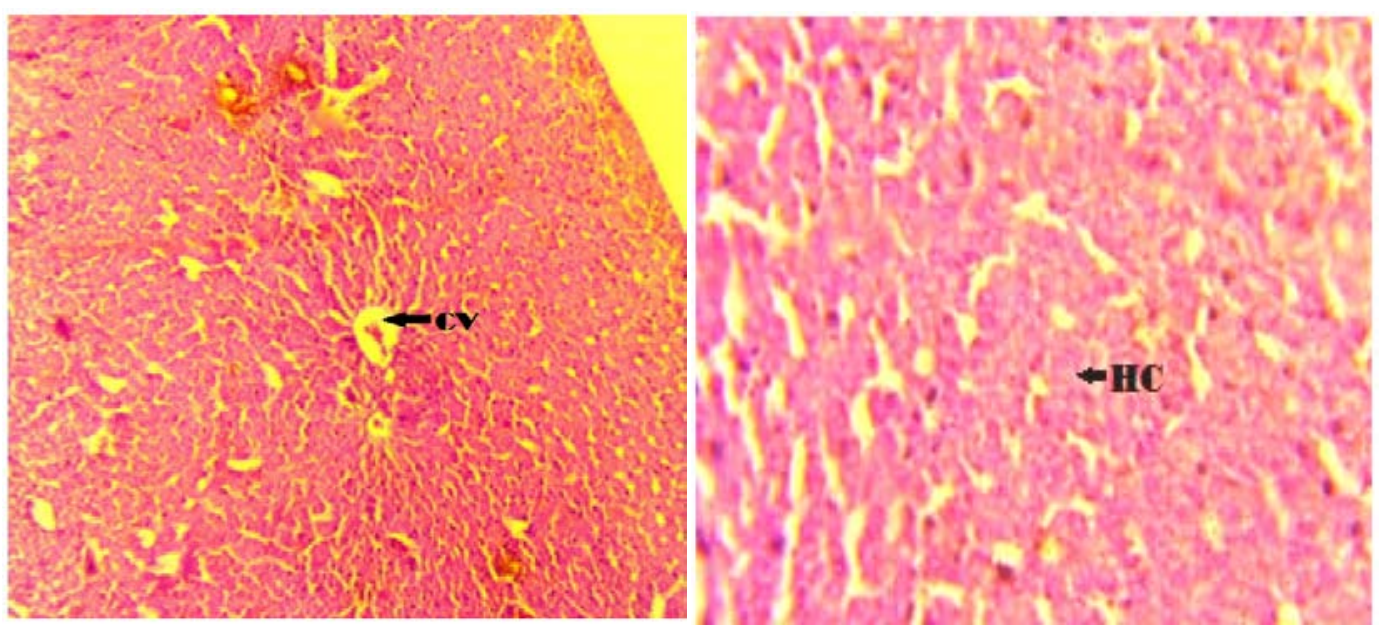

Fig. 3A: Photomicrograph of control liver tissue of freshwater catfish Mystus gulio HC-Hepatic cell, CV-central vein

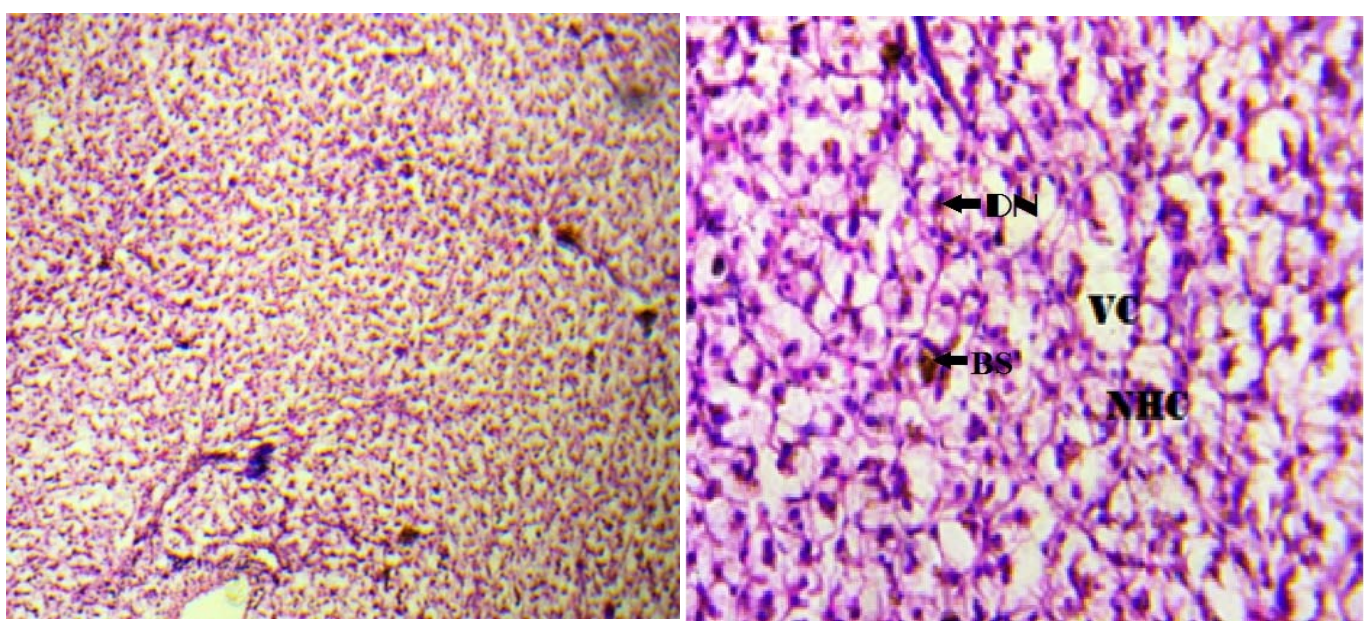

Fig. 3B: Morphology of liver tissue of silver nanoparticle-treated fresh water cat fish Mystus gulio NHC-necrotic hepatic cells, VCvacuolization, DN-disintegrated nucleus BS-blood sinusoids 

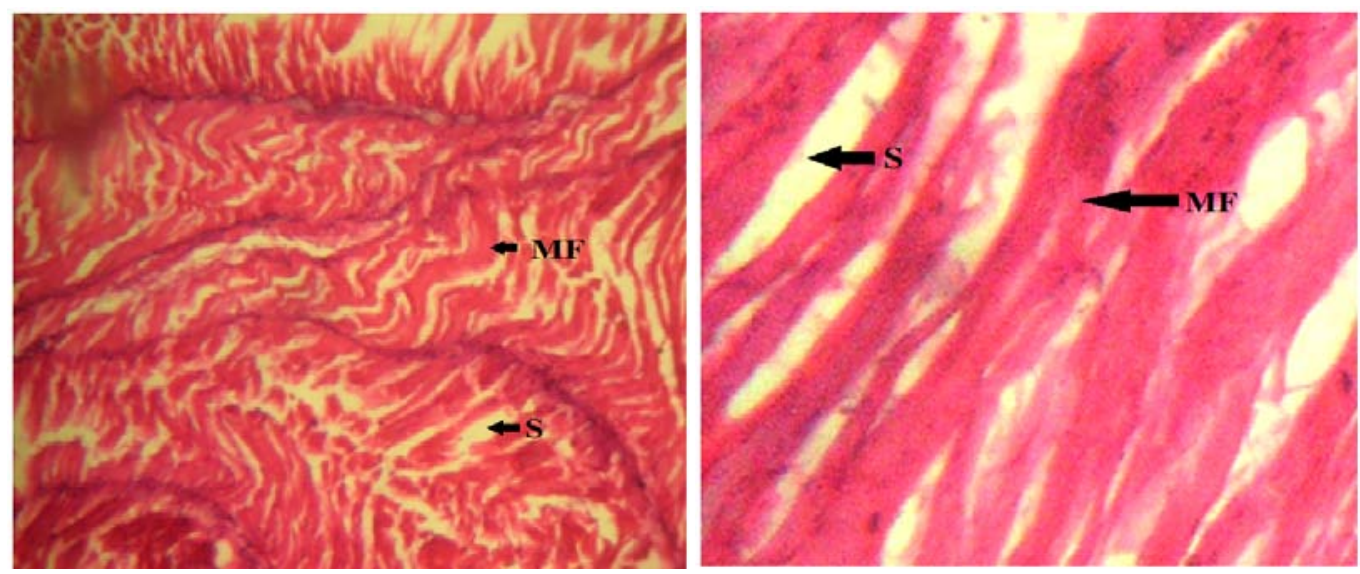

Fig. 4A: Muscle fibers of control fresh water fish Mystus gulio, MF-Myofibrils, S-septum
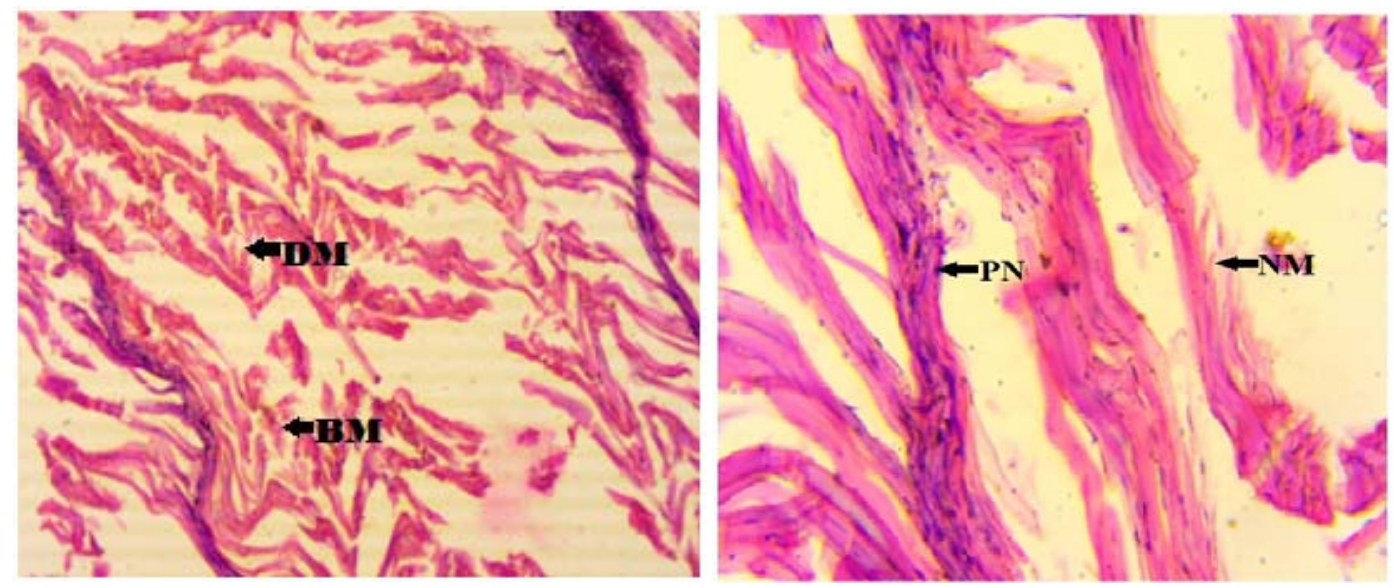

Fig. 4B: Muscle tissue after $15 \mathrm{~d}$ exposure to green synthesized silver nanoparticles the muscle tissue NM-Necrotic Myofibrils, DMdisintegration of myofibrils, PN-pyknotic nucleus

The connective tissue fibre was distinctly discernible. It is evident from the present investigation that disintegration of myofibrils in addition to the pyknotic nucleus was observed in the muscle tissue of green synthesized AgNP's treated group.

\section{DISCUSSION}

The application of silver nanoparticles has become widespread due to their potential antimicrobial properties and used as a preservative in hygienic products. Ultrafine structure of these nanoparticles enables them to penetrate deep into the tissues and disturbs the normal metabolic activity. Green synthesized gold and silver nanoparticles were more effective against HT29 cancer cells [32]. To analyze the toxic nature of these particles Asystasia gangetica mediated synthesized silver nanoparticles were produced. The nanoparticles were characterized by the strong resonance at a particular wavelength. The dipole response of silver nanoparticles, a strong response centred at $430 \mathrm{~nm}$ was observed in the present study. The reduction of metal ions was possibly due to the presence of reducing sugar or terpenoids in the plant extract [33]. The synthesized nanoparticles were stabilized with capping agents [34]. Spherical shape nanoparticle in the size range of 40-60 nm were synthesized.

The biochemical changes were analyzed in control and experimental fishes and the analysis of results shows the reduction in the level of total carbohydrates in the experimental group of animals. Carbohydrates are the primary as well as an immediate energy source [35]. A decline in the carbohydrate levels of gill, muscle, and liver of Oreochromis mossambicus treated with zinc oxide nanoparticles was observed [36], the decrease in the level of carbohydrates may be due to more of utilization towards the energy requirement during stress condition [37]. Reduction in the level of glucose is due to high energy utilization of silver nanoparticletreated goodeid fish Chapalichthys pardalis was observed [38]. The present results are in agreement with previous reports, the administration of green synthesized silver nanoparticles drastically reduced the level of carbohydrates in gills, muscle and liver tissues, the reduction may be due to more utilization of glucose.

The decrease in the level of protein in the liver tissue may be due to overutilization of protein on environmental stress. The increase in energy demand, as well as the altered enzyme activities, will result in the decrease of protein content [39]. In order to manage the stress condition, more of amino acids were utilized for various catabolic activities results in the reduction of total protein [40]. A significant decrease in the level of protein and cholesterol was observed in mercury-exposed fishes [41]. Nanosilver exposure to Brycon cephalus increases the energy demand [42]. It is evident from the previous studies that the decrease in the level of protein in various tissues may be due to the overutilization to overcome the energy crises. The present observation is in line with the previous findings as the total protein content decreased in liver, muscle and gill tissues of the experimental animals further suggest that the administered green synthesized nanoparticles increase the energy demand.

A similar trend has been observed in paper mill effluent treated $A$. testudienus, was a significant rise in the cholesterol level was observed [43]. A rise in the level of cholesterol in Oreochromis niloticus exposed to metals [44]. Improper utilization of lipids by the target tissues such as liver may be the reason for the increase [45]. It is suggested that the increase in the total lipid content of liver and gills proves that the administration of nanoparticles induced 
damages in the structural organization of these tissue as evident from the light microscopic observations. To evaluate the impact of silver nanoparticles on the ionic regulation, $\mathrm{Na}^{+}-\mathrm{K}^{+}$-ATPase activity was observed in liver, muscle and gill tissues of control and silver nanoparticle-treated fresh water fishes. ATPase plays a major role in transporting ions across cell thus maintaining osmotic balance in fish. ATPase was considered as a biomarker to assess the membrane fragility of the gills [46]. In heavy metal treated fishes inhibition or stimulation of ATP-ase activity was observed in gills [47]. A significant increase in $\mathrm{Na}^{+}-\mathrm{K}^{+}$-ATPase activity in the gill tissue of $\mathrm{SiO}_{2}$ treated freshwater fish Labeo rohita [48]. A significant increase of $\mathrm{Na}^{+}-\mathrm{K}^{+}$-ATPase activity in the gut lumen of carbon nanotube exposed fishes [49]. $\mathrm{Na}^{+}-\mathrm{K}^{+}$-ATPase a conserved membrane enzyme in epithelial cells of gills is found to be involved in the ionic regulation [50]. $\mathrm{Na}^{+}-\mathrm{K}^{+}$ATPase was important for hydralize. ATP molecules which provide the required amount of energy for cations transfer [51]. The increase in ATPase activity might be due to restoring the electrolyte losses. The increase of the activity of $\mathrm{Na}^{+}$$\mathrm{K}^{+}$-ATPase is an adaptive mechanism to balance the increased uptake of $\mathrm{Na}^{+}$uptake in the fresh water medium [52]. The intake of water is increased to several folds during stress conditions in freshwater fishes especially in polluted water [53]. Disruption of ATPase enzyme inhibits the uptake of $\mathrm{Na}^{+}$and $\mathrm{Cl}^{-}$ions and thereby disturbs the ionic regulation between the cells [54].

Gills are responsible for regulating the exchange of salt and water even a slight structural damage can render a fish very vulnerable to osmoregulatory as well as respiratory difficulties. AgNPs treated fishes show lamellae fusion and aneurism formation in gills and enlargement of liposomes leading to vascular degeneration of liver [55]. Necrosis was observed in the secondary lamellae of the rainbow trout treated with AgNPs [56]. In the present observation, the vacuolization of the respiration lamellae was disrupted along with the damages evident in the epithelial cells covering the lamellae. Hypotrophy of both primary and secondary lamellae along with disorganization of gill rakers was also evident. Structural organization changes in the histological structure of gill treated fish may be well associated with circulatory disturbance along with the regressive changes [57]. The gills are used to assess the effect of pollutant and the aquatic medium. The results observed in the present study indicated several damages caused by the administration of silver nanoparticles in the aquatic medium. Aphanius dispar the freshwater fish treated with deltamethrin shows vacuolization lifting lamellar epithelium and fusion of secondary lamellae [58]. Irregular polygonal shape hepatocytes of liver cells of Heteropneustes fossilis exposed to Cypermethrin [59]. Dosedependent toxicity of liver and kidney tissues was observed in the intratracheal installation of carbon nanomaterials in rats [60]. Vacuoles, Pyknosis, and Necrosis were evident in the experimental groups. Exposure to polluted water results in changes of enzymatic as well as metabolic activities which leads to pathological lesions in liver [61]. In the present investigation with severe necrosis was observed in AgNP's exposed groups of fishes compared to control. Treatment with nanoparticle shows disruption, deterioration of muscle fiber characterized by fissures and breaks in the muscle fibers. Inflammation in the fibre was observed in AgNP's treated Labeo rohita [55], the disintegration of myofibrils along with pyknotic nuclei was evident in the treated group suggesting the toxic effect of green synthesized silver nanoparticles.

\section{CONCLUSION}

Many studies proved that synthesis of NPs are toxic to the living organism. Synthesis of silver nanoparticles using green plants was implemented to induce the toxicity of colloidal silver. Hence, the present study proves the potential toxic effect of green synthesized nanoparticles. Further analysis are required to study the mechanism and level of toxicity caused by the nanoparticles at the molecular level.

\section{AUTHOR CONTRIBUTION}

Experimental Work and manuscript preparation was done by Miss. T. Abirami

The light microscopic studies were carried out by Mr. Alen Godfrey R Jose
Work Design and correction of manuscript was done by Dr. Bavani Govindarajulu

Design and evaluation of results and final correction of manuscript was done by the corresponding author Dr. J. Karthikeyan

\section{CONFLICT OF INTERESTS}

The authors declare that there is no conflict of interest

\section{REFERENCES}

1. Wieneke H, Sawitowski T, Wendt S, Dirch O, Gu YL, Dahmen U, et al. Nanobeschichtung von koronaren stents zur reduction der neointimlane proliferation. Z Kardiol 2002;91:66.

2. Labille J, Bottero Y. Fate of nanoparticles in aqueous media. Nanoethics Nanotoxicology; 2011. p. 291-324.

3. Lapresta-Fernandez A, Fernandez A, Blasco J. Nanoecotoxicity effects of engineered silver and gold nanoparticles in aquatic organisms. Trends Anal Chem 2012;32:1-20.

4. Chae YJ, Pham CH, Lee J, Bae E, Yi J, Gu MB. Evaluation of the toxic impact of silver nanoparticles on Japanese medaka (Oryzias latipes). Aquat Toxicol 2009;94:320-27.

5. Scown TM, Santos EM, Johnston BD, Gaiser B, Baalousha M, Mitov S, et al. Effects of aqueous exposure to silver nanoparticles of different sizes in rainbow trout. Toxicol Sci 2010;115:521-34.

6. Muhling M, Bradford A, Readman JW, Somerfield PJ, Handy RD. An investigation into the effects of silver nanoparticles on antibiotic resistance of naturally occurring bacteria in an estuarine sediment. Mar Environ Res 2009;68:278-83.

7. Chen D, Qiao X, Qiu X, Chen J. Synthesis and electrical properties of uniform silver nanoparticles for electronic applications. J Material Sci 2009;44:1076-81.

8. Singh R, Lillard JW Jr. Nanoparticle-based targeted drug delivery. Exp Mol Pathol 2009;86:215-23.

9. Zhang C, Wan X, Zheng X, Shao X, Liu Q, Zhang Q, et al. Dualfunctional nanoparticles targeting amyloid plaques in the brains of Alzheimer's disease mice. Biomaterials 2014;35:456-65.

10. Hood E. Nanotechnology, diving into the unknown. Environ Health Perspective 2004;112:747-9.

11. Karthikeyan J, Mullai Nila K, Thooyavan G, Vimalkumar E. Larvicidal and antibacterial efficacy of green synthesized silver nanoparticles using Melia dubia. Int J Pharm Pharm Sci 2014;6:395-9.

12. Kennedy LC, Bickford LR, Lewinski AJ, Coughlin Y, Hu ES, Day $\mathrm{JL}$, et al. A new era for cancer treatment: gold-nanoparticle mediated thermal therapies. Small 2011;7:169-83.

13. Duarah S, Pujari K, Durai RD, Narayanan VHB. Nanotechnologybased cosmeceuticals: a review. Int J Appl Pharm 2016;8:8-12.

14. Reijnders L. The release of $\mathrm{TiO} 2$ and $\mathrm{SiO} 2$ nanoparticles from nanocomposites. Polymer Degradation Stability 2009;94:873-6.

15. Wu Y, Zhou Q, Liu HLW, Wang T, Jiang G. Effects of silver nanoparticles on the development and histopathology biomarkers of Japanese medaka (Oryzias latipes) using the partial-life test. Aquat Toxicol 2010;100:160-7.

16. Yeo MK, Kang M. Effects of nanometer-sized silver materials on biological toxicity during zebrafish embryogenesis. Bull Korean Chem Soc 2008;29:1179-84.

17. Bruneau A, Turcotte P, Pilote M, Gagne F, Gagnon C. Fate of silver nanoparticles in wastewater and immunotoxic effects on rainbow trout. Aquat Toxicol 2016;174:70-8.

18. Khan MS, Qureshi NA, Jabeen F. Assessment of toxicity in fresh water fish Labeo rohita treated with silver nanoparticles. Appl Nanosci 2017;7:167-79.

19. Handy RD, Owen R, Valsami-Jones E. The ecotoxicology of nanoparticles and nanomaterials: current status, knowledge gaps, challenges, and future needs. Ecotoxicology 2008;17:315-25.

20. Franchini A, Alessandrini F, Fantin AMB. Gill morphology and ATPase activity in the goldfish Carassius carassius var. auratus exposed to experimental lead intoxication. Boll Zool 1994;61:29-37.

21. Lovern SB, Strickler JR, Klaper R. Behavioral and physiological changes in daphnia magna when exposed to nanoparticle suspensions (Titanium dioxide, NanoC60, and C60HxC70Hx). Environ Sci Technol 2007;41:4465-70. 
22. Hamilton F. An account of the fishes found in the river Ganges and its branches. Edinburg, London: Nabu Press; 1822. p. 1-39.

23. Senarathne P, Pathiratne KAS. Accumulation of heavy metals in a food fish, Mystus gulio inhabiting Bolgoda Lake, Sri Lanka. J Aquat Sci 2007;12:61-75.

24. Rajkumar M, Kumaraguruvasagam KP, Maheskumar K, Shanmugam A. Effect of lykamin on growth and biochemical composition of long whiskered catfish, Mystus gulio (Hamilton) fingerlings under laboratory conditions. J Indian Fisheries Association 2004;31:115-23.

25. Haniffa MA. Native catfish culture-a technology package for fish farmers. Aquaculture Asia Magazine 2009;14:22-4

26. Lowry OH, Rosebrough NJ, Farr AL, Randall RJ. Protein measurement with the folin phenol reagent. J Biol Chem 1951;193:265-75.

27. DuBois M, Gilles K, Hamilton J, Rebers P, Smith F. Colorimetric method for determination of sugars and related substances. Anal Chem 1956;28:350-6.

28. Frings CS, Dunn RTA. Colorimetric method for determination of total serum lipids based on the sulfo-phospho-vanillin reaction. Am J Clin Pathol 1970;53:89-91.

29. Le Bel D, Poirier GG, Beaudoin AR. A convenient method for ATPase assay. Anal Biochem 1978;85:86-9.

30. Humason GL. Animal Tissue Techniques. WH Freeman, Co, San Francisco; 1967. p. 569.

31. Zar JH. Biostatistical analysis. $2^{\text {nd }}$ eds. Englewood Clifffs NJ, USA: Prentice Hall Inc; 1984

32. Rajasekar A, Janakiraman V, Govindarajan K. In vitro cytotoxic study of green synthesized gold and silver nanoparticles using Eclipta prostrate (L.) against HT-29 cell lines. Asian J Pharm Clin Res 2016;9:189-93.

33. Shankar SS, Rai A, Ahamed A, Sastry M. Rapid synthesis of Au $\mathrm{Ag}$ and silver nanoparticles using Capsicum annum L. extract. Green Chem 2007;9:852-8.

34. Ahamed A, Mukherjee P, Senapati S, Mandal D, Kumar R, Sastri YM. Extracellular biosynthesis of silver nanoparticles using the fungus Fusarium oxysporum. Colloids Surf B 2003;28:313-8.

35. Umminger BL. Relation of whole blood sugar concentration in vertebrate to standard metabolic rate. Comp Biochem Physiol 1977;55:457-69.

36. Rajan MR, Archana J, Ramesh R, Keerthika V. Toxicity of zinc oxide nanoparticles in Tilapia Oreochromis mossambicus. Paripex Indian J Res 2016;5:220-4.

37. Obula RKP. Certain metabolic modulation in carbohydrate metabolism of fry of Cyprinus carpio on ammonia stress. Ph. D thesis, S. V University, Tirupathi, India; 1994.

38. Valerio-Garcia RC, Carbajal-Hernandez AL, Martine-Ruiz EB, Jarquin-Daiz VH, Haro-Perez C, Martinez-Jeronimo F. Exposure to silver nanoparticles produces oxidative stress and affects macromolecular and metabolic biomarkers in the goodeid fish Chapalichthys pardalis. Sci Total Environ 2017;583:308-18.

39. Lett PF, Farmers G], Beamish FWH. Effect of copper on some aspect of the bioenergetics of rainbow trout (Salmo gairdneri). J Fish Res Board Can 1976;33:1335-42.

40. Borah S, Yadav RNS. Impact of sublethal concentration of Assam petroleum crude oil in the muscle of a fresh water fish H. fossilis. J Fresh Water Biol 1996;8:79-82.

41. Arya A, Sharma GD. Combined effect of cadmium and Mercury on some biochemical and histochemical changes in liver, kidney and gills of Channa punctatus (Bloch). Int J Pharm Pharm Sci 2015;7:117-20.

42. Hori TSF, Ailez IM, Inoue LK, Moraes G. Metabolical changes induced by chronic phenol exposure in matrinxa Brycon cephalus (Teleosti: Characidae) juveniles. Comp Biochem Physiol 2006;143:67-72.
43. Nanda P. Bioaccumulation of heavy metals and physiological response in Anabas testudineus on exposure to paper mill effluent. J Environ Anal Toxicol 2014;5:1-8.

44. Oner M, Atli G, Canli M. Changes in serum biochemical parameters of fresh water fish Oreochromis niloticus following prolonged metal $(\mathrm{Ag}, \mathrm{Cd}, \mathrm{Cr}, \mathrm{Cu}, \mathrm{Zn})$ exposure. Environ Toxicol Chem 2008;27:360-6.

45. Nanda P, Panigrahi S, Nanda BR, Behera MK, Kaliali E. Histological changes in climbing perch, Anabas testudineus Block Anabantidae: Perciformes due to three granular insecticides. Environ Ecol 2004;22:24-5.

46. Stagg R, Goksoyr A, Rodger G. Changes in branchial $\mathrm{Na}^{+}, \mathrm{K}^{+}$ ATPase, metallothionein and P450 1Al in dab Limandalimanda in the german bight: indicators of sediment contamination. Mar Ecol Prog Ser 1992;91:105-15.

47. Watson TA, Beamish FWH. Effects of zinc on branchial ATPase activity in vivo in rainbow trout, Saimo gairdneri. Comp Pharmacol 1980;66:77-82.

48. Krishnapriya K, Ramesh M, Saravanan M, Ponpandian N. Ecological risk assessment of silicon dioxide nanoparticles ina fresh water fish Labeo rohita: Hematology, ion-regulation and gill $\mathrm{Na}+/ \mathrm{K}+\mathrm{ATPase}$ activity. Ecotoxicol Environ Safety 2015;120:295-302.

49. Smith CJ, Shaw BJ, Handy RD. Toxicity of single walled carbon nanotubes on rainbow trout, (Oncorhynchus mykiss): respiratory toxicity, organ pathologies and other physiological effects. Aquat Toxicol 2007;82:94-109.

50. Parvez SS, Sayeed I, Raisuddin S. Decreased gill ATPase activities in the freshwater fish Channa punctata (Bloch) exposed to a diluted paper mill effluent. Ecotoxicol Environ Safety 2006;65:62-6.

51. Karthikeyan J, Bavani G. Effect of cadmium on lactate dehydrogenase isoenzyme, succinate dehydrogenase and $\mathrm{Na}^{+}$ $\mathrm{K}^{+}$-ATPase in liver tissue of rat. J Environ Biol 2009;30:859-98.

52. Towle DW. Role of $\mathrm{Na}^{+} / \mathrm{K}^{+}-\mathrm{ATP}$-ase in ionic regulation by marine and estuarine animals. Marine Biol Lett 1981;2:107-22.

53. Best JH, Eddy FB, Codd GA. Effects of Microcystis cells, cell extracts and lipopolysaccharide on drinking and liver function in rainbow trout Oncorhynchus mykiss Walbaum. Aquat Toxicol 2003;64:419-26.

54. Monfared AL, Bahrami AM, Hosseini ES, Soltani S, Shaddel M. Effects of nanoparticles on histo-pathological changes of the fish. J Environ Health Sci Engg 2015;13:2-5.

55. Rajkumar KS, Kanipandian N, Thirumurugan R. Toxicity assessment on hematology, biochemical and histological alterations of silver nanoparticles-exposed freshwater fish Labeo rohita. Appl Nanosci 2016;6:19-29.

56. Govindasamy R, Rahuman AA. Histological studies and oxidative stress of synthesized silver nanoparticles in Mozambique tilapia (Oreochromis mossambicus). J Environ Sci 2012;24:1091-8.

57. Van Dyk JC, Marchand MJ, Pieterse GM, Barnhoorn IEJ, Bornman MS. Histological changes in the gills of Clarias gariepinus (Teleostei: Clariidae) from a polluted South African urban aquatic system. Afr J Aqua Sci 2009;34:283-91.

58. Al-Ghanbousi R, Ba-Omar T, Victor R. Effect of deltamethrin on the gills of Aphanius dispar. A microscopic study. Tissue Cell 2012;44:7-14.

59. Joshi N, Dharmlata, Sahu AP. Histological changes in liver of Heteropneustes fossilis exposed to cypermethrin. J Environ Biol 2007;28:35-7.

60. Angoth B, Lingabathula $\mathrm{H}$, Yellu N. Assessment of extrapulmonary toxicity induced by carbon nanomaterials following intra-tracheal instillation in rats. Asian J Pharm Clin Res 2017;10:82-7.

61. Prabha PS, Rajkumar J. Histological study of protective effect of aquatic weed Hydrilla verticillata against lead induced toxicity in fish. Int J Pharm Pharm Sci 2015;7:132-6. 